\title{
The Evaluation of a Turkish Literature Coursebook According to the Constructivist Learning Approach
}

\author{
Gürbüz OCAK*
}

Received: 04 May 2012

Accepted: 17 April 2013

\begin{abstract}
The purpose of this study is to determine the level of congruence of a ninth grade Turkish literature coursebook with the constructivist approach. Data in the study were collected through the "Constructivist Coursebook Evaluation Scale" which is a 5-point Likert type scale developed by the researcher. The reliability coefficient of the scale was calculated as .88 and the scale consists of four sub-dimensions, namely, introduction, teaching, format, and assessment. The scale was administered to six different observers and mean scores of those were calculated for each sub-dimension. According to the findings of the study, the introduction criteria of the textbook (except the first unit) were not sufficient enough. According to the teaching criteria, all units of the textbook are less sufficient. According to the format criteria, the first unit is sufficient enough while the others were less sufficient. According to the assessment criteria, the third unit is less sufficient while the others were much less sufficient. According to the results of one-way analysis of variance done, differences between units in terms of activities were significant. It can also be concluded that the third unit was less sufficient in terms of constructivist learning while the others were much less when overall mean scores of each unit examined,
\end{abstract}

Keywords: constructivist approach, coursebook, Turkish literature.

\section{Extended Abstract}

Purpose and Significance: The aim of this study is to determine the level of congruence of ninth grade Turkish literature coursebooks used in secondary schools with the constructivist learning approach. Within this framework, the research question, "According to the pre-determined criteria, what is the congruence level of a Turkish literature coursebook with constructivism?” was addressed.

Method: The population of the study consisted of ninth grade Turkish literature coursebooks of different publishers that have been in accordance with the renewed Turkish literature curriculum and adopted by the Ministry of National Education (MoNE) while the sample, a ninth grade Turkish literature coursebook of Kurt et al. (2009) determined through random sampling among those distributed by the MoNE in Afyonkarahisar for the 2009-2010 academic year. In this study, the ninth grade Turkish literature coursebook was analyzed according to the Turkish literature curriculum, and through the "Constructivist Coursebook Evaluation Scale (CCES)" developed by Küçüközer Bostan, Kenar, Seçer and Yavuz (2008) and Ocak and Yurtseven (2009) based on the constructivist learning approach. All units of the coursebook ("Fine Arts and Literature”, “Texts of Enthusiasm and Excitement (Poetry)”, "Event-Based Literary Texts”, “Tutorial Texts”) were examined. The scale developed on the basis of expert review and the literature review is a 5-point Likert type scale (5: more sufficient, 4 :

\footnotetext{
*Assoc. Prof. Dr., Afyon Kocatepe University, Afyonkarahisar, Turkey, gocak@aku.edu.tr
} 
sufficient, 3: less sufficient, 2: much less sufficient, 1: insufficient). In addition, the four sub-dimensions of the CCES (introduction, teaching, format, and assessment) were examined.

Results: In terms of introduction criteria; what is the congruence level of unit activities with the constructivist learning approach? The first unit was found sufficient while the second and third units were less sufficient. The fourth unit was much less sufficient according to the introduction criteria. Introductory activities should reveal prior knowledge of students and be in particular so that they can help students establish a relationship between previous and further knowledge. However, as emerged from observations, these measures were not sufficient in the ninth grade Turkish literature coursebook. In terms of teaching criteria, what is the congruence level of unit activities with the constructivist learning approach? While observers stated that the first and second units' reading texts arouse much less wonder of research on the authors, they indicated that not any wonder of research can be found in the third and fourth units. These findings showed that the ninth grade Turkish literature coursebook was insufficient in terms of research skills that should be developed as advocated by the constructivist learning theory. When overall mean scores of the teaching criteria examined, "Fine Arts and Literature" unit with an average of 3.18, "Texts of Enthusiasm and Excitement (Poetry)" unit with an average of 3.01, "Event-Based Literary Texts" unit with an average of 3.01, and "Tutorial Texts" unit with an average of less than 2.79 were found less sufficient. In terms of format criteria, what is the congruence level of unit activities with the constructivist learning approach? According to the average scores of the format criteria, it was found that the first unit was sufficient while the others were less sufficient. In terms of the assessment criteria, what is the congruece level of unit activities with the constructivist learning approach? The observers stated that traditional measurement and assessment tools were mostly used and complementary measurement tools were either much less or not used in the Turkish literature coursebook. Although tables of self-critique at the end of each topic in the textbook can be used for self-assessment, the observers did not find those sufficient. Peer assessment was provided in the third exercise of the text, Hamlet in the "Theatre" topic. However, it was found much less sufficient. Giving more space to fill-in-theblank, multiple-choice, and true-false questions than complementary measurement tools after each unit can be considered as an indicator of a still traditional ninth grade Turkish literature coursebook. According to the one-way analysis of variance results, the mean score of the first unit on the introduction criteria was the highest (3.49) while the fourth unit the lowest (2.43). Differences between the units in the textbook in terms of introductory activities were significant $(p<.05)$. According to the Tukey's HSD test results, the first unit was significantly different $(p<.05)$ from the other units. However, there were nonsignificant differences within the other criteria (teaching, format, and assessment) at the unit level ( $p>.05)$. According to the results of one-way analysis of variance done regarding all criteria, there were significant differences between units 
$(p<.05)$. The Tukey's HSD test results showed that differences were due to the averages of the first and the fourth units. Differences between these units were significant $(p<.05)$.

Discussion and Conclusions: According to the overall mean of the scale unit by unit, it was found that the third unit in the coursebook was less sufficient in terms of constructivist learning while the other three units were much less sufficient. In this sense, reorganization of the ninth grade Turkish literature coursebook in accordance with the constructivist learning approach is important for the curriculum. Although use of coursebooks are not much appreciated by the constructivist learning approach, it will be useful to modify coursebooks in accordance with constructivist learning, considering the fact teachers in our country have still not taught without coursebooks. The coursebook used during the teaching-learning process in the classroom should improve students' reading and higher order thinking skills, and construct forthcoming knowledge on the basis of their prior knowledge. 


\title{
Türk Edebiyatı Ders Kitabının Yapılandırmacı Öğrenme Yaklaşımına Göre Değerlendirilmesi
}

\author{
Gürbüz OCAK*
}

Makale Gönderme Tarihi: 04 Mayıs 2012

Makale Kabul Tarihi: 17 Nisan 2013

\begin{abstract}
ÖZET: Bu araştırmanın amacı, ortaöğretim 9. sınıflarda okutulan Türk Edebiyatı ders kitabının yapılandırmacı öğrenme yaklaşımına göre hazırlanmış ölçütlere uygunluk düzeyini belirlemektir. Çalışmada veriler araştırmacı tarafından 5'li derecelendirme şeklinde oluşturulan "Yapılandırmacı Ders Kitabı Değerlendirme Ölçeği” ile toplanmıştır. Güvenirliği .88 olarak hesaplanan ölçek, giriş, öğretim, biçim, değerlendirme olmak üzere dört alt boyuttan oluşmaktadır. Ölçek, ders kitabı incelenerek altı ayrı gözlemci tarafından doldurulmuş ve gözlemcilerin her bir ölçüt için verdikleri puanların ortalamaları hesaplanmıştır. Araştırmadan elde edilen bulgulara göre; ders kitabının giriş ölçütleri, birinci ünite dışında, yeterli bulunmamıştır. Öğretim ölçütlerine göre; ders kitabının tüm üniteleri az yeterli; biçim açısından birinci ünite yeterli, diğer üniteler az yeterli; değerlendirme açısından üçüncü ünite az yeterli, diğer üniteler ise çok az yeterli bulunmuştur. Üniteler arasındaki farkın anlamlılığını belirlemek için yapılan tek yönlü varyans analizi sonucuna göre, giriş etkinlikleri açısından üniteler arasındaki fark anlamlıdır. Yapılan araştırmada kullanılan ölçeğin ünitelere göre genel ortalaması incelendiğinde, ders kitabında üçüncü ünitenin yapılandırmacı öğrenme anlayışı açısından az yeterli olduğu, diğer üç ünitenin ise çok az yeterli olduğu sonucuna ulaşılmıştır.
\end{abstract}

Anahtar Kelimeler: yapılandırmacı yaklaşım, ders kitabı, Türk Edebiyatı.

\section{Giriş}

Kuhn (1970)'in belirttiği gibi, bilimde değişim kesintilidir ve devrim şeklindedir. Belli bir dönem belli bir bilimsel çalışma alanına egemen olan paradigma (kuram, dünya görüşü) zamanla gücünü yitirir ve düşme eğilimi göstermeye başlar. Bu paradigma, zamanla, bir yenisi ile yer değiştirir (Aktaran: Şimşek, t.y.). Tek bir doğrunun olmadığını iddia eden pozitivizm ötesi ve akılcılık ötesi paradigma gerçeğin, bilginin ve doğrunun sosyal kurgular olduğunu ileri sürerek insanların anlamların yaratılması sürecine etkin bir biçimde katıldığını ileri sürer. Bilginin oluşturulması ve sunulmasında tek ve en doğru yolun olmadığını ifade ederler (Yıldırım \& Şimşek, 2000). Bir başka deyişle, bireyler anlamın dolayısıyla bilginin oluşturulmasında aktif olarak rol almaktadırlar. Bilginin oluşturulmasında değişen bu anlayış, öğrenme anlayışını da değiştirmiştir. Bireyin bilgiyi yorumlama, oluşturma süreci olarak değişen öğrenme anlayışının temelinde bireyin önceden oluşturduğu düşünme süreçleri, deneyimleri, gözlem ve incelemeleri, gerçek problemleri ve bunların çözümüne yönelik hipotezleri vardır. Değişen bu öğrenme anlayışı, kökeni Kant’a (18. yy. sonu-19. yy. başı) (Loyens, 2007) dayanan yapılandırmacı öğrenme anlayışını ortaya çıkarmıştır. Yapılandırmacı öğrenme anlayışında bilgi öğrenen tarafından elde edilir. Bilginin derin anlamı, sadece kazanım ve birikim ile değil, bilginin transferi ve yapılandırılmasının bir sonucu olarak elde edilir (Blumenfeld, 1992). Bilginin oluşturulmasının arkasındaki temel fikir, öğrenenlerin önceden elde ettikleri bilgiyi kullanarak yeni bilgiyi yorumlamasıdır (Loyens, Rikers, \& Schmidt, 2007). Yapılandırmacı öğrenmede temel amaç, bilginin yeniden yorumlanmasıdır. Öğrenenin bilgiyi geçmiş deneyimlerine dayalı olarak anlayabileceği biçimde yeniden oluşturması, öğrenmeye bilgiyi

*Doç. Dr., Afyon Kocatepe Üniversitesi, gocak@aku.edu.tr 
yapılandırıcı bir görüş kazandırmıştır. Buradaki temel vurgu, öğrencinin bilgiden kendine özgü bir anlam çıkarmasıdır.

Yapılandırmacı öğrenmenin boyutlarından birini işbirliği oluşturur. Bilgi öğrenenin, diğer öğrenciler ve öğretmen ile sosyal etkileşimi sonucu oluşur. Öğrenme ortamı içerisinde oluşturulan olumlu ilişkiler, motivasyon ve paylaşım öğrencilerin öğrenmesini anlamlı bir şekilde etkileyecektir. Yapılandırmacı öğrenme ile oluşturulan özgüven ile öğrenciler günlük hayatta karşılaştıkları problemleri çözebilme becerisi kazanmaktadırlar çünkü yapılandırmacı öğrenme yaklaşımında öğrencinin gerçek hayatta karşılaşabileceği karmaşık problemler, öğrenmenin bir başka temelini oluşturur. Ar1 ve Bayram (2012) yapmış oldukları araştırmadan elde ettikleri sonuçlar, geleneksel yönteme göre öğrencilerin akademik başarı, bilimsel süreç becerileri ve laboratuvar performanslarının, yapılandırmacı yaklaşım ile, daha üst seviyelerde gerçekleşebildiğini göstermektedir.

Yapılandırmacı öğrenme yaklaşımı, öğrencilerin nasıl algıladıklarını ve sentezlediklerini araştırır. Teorik bir akılcılık olarak, araştırma ve incelemeyi, gerçek dünya problemlerine dayalı olarak öğrencinin, bireyin, bu gerçek yaşantılarından deneyimler edinerek bir sonraki süreçte karşılaşabileceği problemleri bu deneyimlere dayalı olarak çözmesini ön plana çıkarmayı hedefler (Yaşar, 1998: 69).

Yapılandırmacı anlayış ile birlikte öğretmenin de rolü değişmiştir. Öğretime ilişkin birçok yaklaşımda olduğu gibi yapılandırmacı öğrenmede de öğretmen, öğrencilerin önceki ve yeni karşılaştıkları bilgileri nasıl bağlantı kurarak yapılandıracaklarına rehberlik eder. Öğretmenler aynı zamanda öğrencilerin düşünme becerilerini geliştirmelerinde onlara öncülük, modellik ederek yardımcı olur. Öğretim ortamını düzenlemede, içeriği çoklu yöntemlerle sunmada da önemli bir rol oynar (Duman, 2004:62).

Yapılandırmacı öğrenme yaklaşımında bilgi, dış bir kaynaktan olduğu gibi alınmaz. Bunun yerine birey bilgiyi kendisi üretir ya da var olan bilgiyi kendisi keşfeder. $\mathrm{Bu}$ açıdan bakıldığında yapılandırmacı yaklaşım öğretmen ve öğrencinin rolünü değiştirdiği gibi ders kitabının da rolünü değiştirmiştir. Ders kitapları öğrenciye bilgiyi yapılandırma sürecinde yardımcı olan, onları düşünmeye sevk eden, eleştirel bakış açısı kazanmasına yardımcı olan, çoklu bakış açısı ile değerlendirme yapmasına katkıda bulunan birer öğretim aracı hâline gelmiştir.

Şüphesiz, kaliteli eğitimin gerçekleşebilmesinin önemli etkenlerinden biri de kaliteli ders kitaplarıdır. Kitaplar, öğrencilere öğretim programları ile ilgili bilgiler sağlayan, belirli ipuçları veren ve onlara toplumun istediği davranışları kazandıran, onları araştırma ve incelemeye yönlendiren, onlara en uygun öğrenme ve öğretme olanağı sunan araçlardan biridir (Kılıç, 2005: 39, aktaran Demirci, 2008). Şüphesiz, ders kitapları diğer öğrenme yaklaşımlarında olduğu gibi yapılandırmacı öğrenme yaklaşımında da bir araç olarak görülmektedir. Köseoglu ve diğerleri (2003) yapılandırmacı öğrenme ortamında ders kitaplarının nasıl olması gerektiğini, "Öğretimin bir parçası olan içerik, doğrudan ne ders kitaplarında ne de başka bir kaynakta yer alır. Bu kaynaklar sadece araçlardır.” şeklinde ifade etmişlerdir.

Milli Eğitim Bakanlığı Ders Kitapları ve Eğitim Araçları Yönetmeliği (1995)’te ders kitabı, “Örgün ve yaygın eğitim kurumlarında kullanılmak üzere, içeriği öğretim 
programları doğrultusunda hazırlanmış, gerektiğinde fasikül hâlinde de üretilebilen basılı eser" olarak tanımlanmıştır. Ders kitapları, gerek sınıf içinde gerekse sınıf dışında öğretmen ve öğrencinin vazgeçemeyeceği en temel araçlardan biridir. Öğrenci ders kitaplarını sınıf içi eğitim ortamlarında öğretmen gözetiminde kullanırken sınıf dışında da bireysel öğrenme amaçlı kullanabilmektedir. Çoğu öğretmen için ders kitapları eğitim programının yerini almakta, öğretmen kazanımların belirlenmesinden değerlendirmeye kadar tüm eğitim durumlarında ders kitabını ön plana çıkartmaktadır. Ders kitaplarının bu denli önemli olduğu bir eğitim sürecinde ders kitaplarının değerlendirilmesi önem kazanmaktadır.

2005 yılında ülkemizde, ilköğretim okullarında yapılandırmacı öğrenme anlayışı benimsenmiş ve kademeli olarak ortaöğretim kurumlarında da uygulanmaya başlanmıştır. Yapılandırmacı öğrenmeye geçiş ile birlikte ders kitapları da bu anlayışa uygun olarak hazırlanmaya başlanmıştır. Ancak hazırlanan ders kitaplarının öğrencilerin anlamlı öğrenmesini hedefleyen yapılandırmacı öğrenmeye uygunluğu gündeme gelmiştir. Yapılandırmacı öğrenmede ders kitaplarının geleneksel anlayış ile hazırlanan ders kitaplarından farklı olması gerekir. Yapılandırmacı öğrenmede öğrencinin düşünen, bilgiyi yapılandıran, problem çözme becerileri gelişmiş birey olması amaçlanır. Ders kitaplarının da öğrenciyi düşünmeye yönlendiren, günlük hayattan seçilmiş problem örnekleri ve etkinliklerle zenginleştirilmiş, bireyin bilgiyi yeniden yorumlamasına katk1 sağlayan araçlar olarak hizmet etmesi gerekir. Kitapların hazırlanmasında yapılandırmacı öğrenmenin ilkelerine dikkat edilmesinin bireylerin öğrenmeyi gerçekleştirmesine önemli katkıları olacaktır.

$\mathrm{Bu}$ nedenle bu araştırmada ortaöğretim 9. sınıf Türk Edebiyatı dersinin yapılandırmacı öğrenme ilkeleri açısından değerlendirilmesi amaçlanmıştır.

\section{Araştırmanın Amacı}

$\mathrm{Bu}$ araştırmanın amacı, ortaöğretim 9. sınıflarda okutulan Türk Edebiyatı ders kitabının yapılandırmacı öğrenme yaklaşımına göre hazırlanmış ölçütlere uygunluk düzeyini belirleyerek bu alanda hazırlanan yeni ders kitaplarına fayda sağlamaktır.

\section{Araştırmanın Problemi}

Türk Edebiyatı ders kitabında yer alan ünite etkinliklerinin yapılandırmacı anlayışa uygunluk düzeyi nedir?

\section{Araştırmanın Alt Problemleri}

- Giriş bölümü ölçütleri açısından ünite etkinliklerinin yapılandırmacı öğrenme yaklaşımına uygunluk düzeyi nedir?

- Öğretim bölümü ölçütleri açısından ünite etkinliklerinin yapılandırmacı öğrenme yaklaşımına uygunluk düzeyi nedir?

- Biçim ölçütleri açısından ünite etkinliklerinin yapılandırmacı öğrenme yaklaşımına uygunluk düzeyi nedir? 
- Değerlendirme ölçütleri açısından ünite etkinliklerinin yapılandırmacı öğrenme yaklaşımına uygunluk düzeyi nedir?

- Giriş, öğretim, biçim ve değerlendirme ölçütlerine göre gözlemci ortalamaları arasında üniteler açısından anlamlı bir farklılık var mıdır?

\section{Sinırlılıklar}

Bu araştırma 9. sınıflarda okutulan Kurt, Demir, Berber, Çiftçi, Özlük vd. (2009) tarafından hazırlanan Türk Edebiyatı ders kitabı ile sınırlıdır.

Çalışma, kaynak taraması ve uzman kanısına dayalı geliştirilen "Yapılandırmacı Türk Edebiyatı Kitap Değerlendirme Ölçeği”nde belirtilen önermelerle sınırlıdır.

\section{Yöntem}

Araştırmanın çalışma evrenini, yenilenen Türk Edebiyatı programına uygun olarak farklı yayınevleri tarafından hazırlanan Milli Eğitim Bakanlığı (MEB) tarafından kabul edilen 9. sınıf Türk Edebiyatı ders kitapları; araştırmanın örneklemini ise 20092010 eğitim-öğretim y1lında Afyonkarahisar ilinde MEB tarafından ders kitabı olarak dağıtılan kitaplar arasından seçkisiz atama yoluyla belirlenen Kurt, Demir, Berber, Çiftçi, Özlük vd.(2009) tarafından hazırlanan 9. sınıf Türk Edebiyatı ders kitabı oluşturmaktadır.

Bu çalışmada Türk Edebiyatı eğitim programına göre hazırlanan 9. sınıf Türk Edebiyatı ders kitabı incelenmiştir. Çalışma, döküman analizine dayalı olarak yürütülmüştür. Döküman analizinde verilerin standart olarak toplanabilmesi ve yorumlanabilmesi için veri toplama aracı olarak araştırmacı tarafından hazırlanan "Yapılandırmacı Ders Kitabı Değerlendirme Ölçeği” kullanılmıştır.

Ölçek maddelerinin oluşturulmasında Küçüközer, Bostan, Kenar, Seçer ve Yavuz (2008) ile Ocak ve Yurtseven (2009) tarafindan hazırlanan "Yapılandırmac1 Kitap Değerlendirme Ölçeği”den yararlanılmıştır. Hazırlanan ölçek maddeleri, Eğitim Bilimleri Bölümü Eğitim Programları ve Öğretim Anabilim Dalından bir, Türkçe Eğitimi Bölümünden bir ve Türk Edebiyatı dersini veren bir öğretmenden oluşan toplam üç uzmanın görüşüne ve kaynak taramasına dayalı olarak beşli dereceleme ölçeği biçiminde düzenlenmiştir. Hazırlanan ölçek, "5: Çok yeterlidir, 4: Yeterlidir, 3: Biraz yeterlidir, 2: Çok az yeterlidir, 1: Yetersizdir" şeklinde derecelendirilmiştir. "Yapılandırmacı Ders Kitabı Değerlendirme Ölçeği (YDKDÖ)”, giriş, öğretim, biçim, değerlendirme olmak üzere dört temel bölümün içeriğinin analizinde kullanılmıştır.

YDKDÖ’nün giriş bölümünde toplam beş; öğretim bölümünde ondokuz; biçim bölümünde dört ve değerlendirme bölümünde sekiz ölçüt bulunmaktadır. Ölçeğin güvenirliğini hesaplayabilmek için iki gözlemcinin yapmış olduğu puanlama arasındaki korelasyona bakılmış ve ölçeğin güvenirliği .88 bulunmuştur. Büyüköztürk (2007)’ye göre güvenirlik katsayısının .70 ve daha yüksek olması, ölçeğin güvenirliği için genel olarak yeterli görülmektedir.

Objektif ve güvenilir bir değerlendirme yapabilmek amacıyla 9. sınıf Türk Edebiyatı ders kitabı, bu dersi okutan öğretmen ve bu alanda altı yüksek lisans öğrencisi 
tarafindan YDKDÖ ölçütlerine uygun olarak incelenmiş ve bu altı gözlemcinin ortalamaları dikkate alınarak maddeler, "Aralık Genişliği = Dizi Genisliği / Yapılacak Grup Sayısı” formülünden (Tekin, 1996) yararlanılarak hesaplanan 4/5 $=0.80$ puan aralıklarına göre oluşturulan tablo dikkate alınarak değerlendirilmiştir.

Tablo 1

Aralık Tablosu

\begin{tabular}{lcc}
\hline Ölçüt & \multicolumn{3}{c}{ Aralık değeri } \\
\hline Çok yeterli & 5.00 & 4.20 \\
Yeterli & 4.19 & 3.40 \\
Az yeterli & 3.39 & 2.60 \\
Çok az yeterli & 2.59 & 1.80 \\
Hiç yok & 1.79 & 1.00 \\
\hline
\end{tabular}

\section{Bulgular ve Yorum}

Kitabın tüm üniteleri (“Güzel Sanatlar ve Edebiyat”, "Coşku ve Heyecanı Dile Getiren Metinler (Şiir)”, "Olay Çevresinde Oluşan Edebi Metinler", "Öğretici Metinler") incelenmiştir. Oluşturulan ölçütlere göre altı gözlemci tarafından yapılan incelemelerin değerlendirilmesi amacıyla bir değerlendirme tablosu hazırlanmıştır. Tablo 2'de görüldügü gibi altı gözlemcinin değerlendirme ölçütlerine verdikleri puanların ortalamaları hesaplanmıştır.

Giriş Bölümü Ölçütleri Açısından Ünite Etkinliklerinin Yapılandırmacı Öğrenme Yaklaşımına Uygunluk Düzeyi Nedir?

Ön bilgileri ortaya çıkarıcı etkinlikler, gözlemciler tarafından (Tablo 2) Tablo 1'de yer alan referans değerlerine göre az yeterli bulunmuştur. "Edebiyatın Bilimlerle İlişkisi” konusunun hazırlık soruları yetersizdir. 1. soru, “Tarih, sosyoloji, matematik, fizik, kimya, biyoloji, tıp ve psikoloji gibi bilim ve bilgi dallarının hangi konuları kapsadığını belirleyerek defterinize yazınız (s. 6).” konuyla ilgili ön bilgileri ortaya çıkaracak düzeydedir. Ancak 2. soru, "Derslerde konuyla ilgili birden fazla aracın kullanılması ve dersin işlenişinde farklı yöntemlere başvurulması ele alınan konunun kavranma sürecini nasıl etkiler? Tartışınız (s. 6)" farklı bir konuyla ilgilidir. 3. soruya "Diğer bilim alanlarını edebiyatın içinde düşününüz. Nasıl bir sonuç ortaya çıkardı?” şeklinde öğrenciyi konuya hazırlayacak bir soru eklenebilir.

Dikkat çekici etkinlikler yeterli bulunmuştur. Her parçadan önce öğrencide ilgi uyandırıc1 etkinliklere yer verilmiştir. "Dilin Insan ve Toplum Hayatındaki Yeri ve Önemi” konusunun 1. etkinliği (s. 9) dikkat çekiciliğe örnektir. 
Tablo 2

YDKDÖ’ye Göre Ünitelerden Elde Edilen Veriler

\begin{tabular}{|c|c|c|c|c|}
\hline ÖLÇÜTLER & $\begin{array}{c}\text { Ünite } \\
1\end{array}$ & $\begin{array}{l}\text { Ünite } \\
2\end{array}$ & $\begin{array}{c}\text { Ünite } \\
3\end{array}$ & $\begin{array}{l}\text { Ünite } \\
4\end{array}$ \\
\hline A. Giriş & Ort. & Ort. & Ort. & Ort. \\
\hline 1. Ön bilgileri ortaya çıkartıcı etkinliklerin yeterlilik düzeyi nedir? & 3.33 & 3.33 & 2.83 & 2.33 \\
\hline 2. Konudan önceki dikkat çekici etkinliklerin yeterlilik düzeyi nedir? & 4.16 & 2.83 & 2.16 & 2.33 \\
\hline 3. Eski ve yeni öğrenmeler arasında ilişki kurulması sağlanmış mı? & 3.33 & 2.50 & 3.00 & 2.50 \\
\hline 4. Güdüleme yapılmış mı? & 3.00 & 2.33 & 2.50 & 2.33 \\
\hline $\begin{array}{l}\text { 5. Konudan önceki hazırlık soruları yeterince ilgi ve merak uyandırıcı düzeyde } \\
\text { mi? }\end{array}$ & 3.66 & 2.66 & 2.66 & 2.66 \\
\hline Genel Ortalama & $\begin{array}{c}3.49 \\
\mathrm{Y}\end{array}$ & $\begin{array}{l}2.73 \\
\mathrm{AY}\end{array}$ & $\begin{array}{l}2.63 \\
\mathrm{AY}\end{array}$ & $\begin{array}{l}2.43 \\
\text { ÇAY }\end{array}$ \\
\hline \multicolumn{5}{|l|}{ B. Öğretim } \\
\hline 1. Etkinlikler zihinsel becerileri geliştirici düzeyde mi? & 3.00 & 3.16 & 3.00 & 2.66 \\
\hline 2. Etkinlikler öğrencilerin yapabilecekleri düzeyde mi? & 3.66 & 3.00 & 2.66 & 2.83 \\
\hline 3. Metinler orijinaline sadık kalınarak verilmiş mi? & 4.50 & 4.33 & 4.16 & 4.16 \\
\hline 4. Metinlerdeki sadeleştirme yeterli mi? & 4.00 & 3.16 & 3.66 & 3.00 \\
\hline 5. Bilginin öğrenci zihninde yapılanmasını sağlayan durumlar ortaya konmuş mu? & 3.00 & 2.83 & 2.83 & 2.33 \\
\hline $\begin{array}{l}\text { 6. Ders kitabı Türk dilinin etkili ve güzel kullanılmasına örnek olacak ve } \\
\text { özendirecek şekilde düzenlenmiş mi? }\end{array}$ & 2.83 & 3.33 & 3.00 & 3.00 \\
\hline 7. Ünitelerdeki metinler romanın tamamını okumaya yöneltmekte yeterli mi? & 2.16 & 2.40 & 2.33 & 2.20 \\
\hline $\begin{array}{l}\text { 8. Roman veya hikâyelerden alınan parçalar yazarı hakkında öğrencide araştırma } \\
\text { yapma isteği uyandırıyor mu? }\end{array}$ & 2.00 & 2.00 & 1.66 & 1.20 \\
\hline 9. Hayal gücünü geliştirici bölümler var mı? & 3.00 & 3.00 & 3.16 & 2.33 \\
\hline 10. Farklı zeka türlerine yönelik etkinlikler yeterli mi? & 2.16 & 2.33 & 2.16 & 2.16 \\
\hline 11. Kullanılan görsel öğeler ne düzeyde model olmaktadır? & 2.00 & 2.83 & 2.83 & 2.00 \\
\hline 12. Metinlerde günlük hayatla ilişki kurulma düzeyi nedir? & 3.16 & 3.00 & 3.16 & 3.00 \\
\hline 13. Etkinliklerin birbiri ile tutarlılık düzeyi nedir? & 3.50 & 4.00 & 3.16 & 3.50 \\
\hline $\begin{array}{l}\text { 14. Problemler, olaylar üzerinde yeni fikir ve çözümler buldurucu etkinlikler } \\
\text { yeterli mi? }\end{array}$ & 3.50 & 2.50 & 3.50 & 2.66 \\
\hline 15. İçerik ve etkinlikler yorum gücünü ne düzeyde geliştirmektedir? & 3.66 & 2.83 & 3.33 & 3.16 \\
\hline 16. Öğrencileri grup çalışmasına yöneltici aktiviteler mevcut mu? & 3.50 & 2.50 & 3.33 & 3.33 \\
\hline 17. Öğrencinin bilgileri düşünme, anlama ve sorgulaması yeterince sağlanmış mı? & 3.66 & 2.66 & 3.00 & 2.83 \\
\hline 18. Metinlerdeki imla ve noktalamaların doğru kullanılma düzeyi nedir? & 4.16 & 4.33 & 4.33 & 4.00 \\
\hline $\begin{array}{l}\text { 19. Drama, beyin firtınası, gösteri, proje gibi yöntem ve tekniklerin } \\
\text { kullanılmasına uygun etkinlikler var mı? }\end{array}$ & 3.00 & 3.00 & 3.33 & 2.66 \\
\hline Genel Ortalama & $\begin{array}{l}3.18 \\
\text { AY }\end{array}$ & $\begin{array}{l}3.01 \\
\text { AY }\end{array}$ & $\begin{array}{l}3.01 \\
\text { AY }\end{array}$ & $\begin{array}{l}2.79 \\
\mathrm{AY}\end{array}$ \\
\hline \multicolumn{5}{|l|}{ C. Biçim } \\
\hline 1. Metin ve başlık puntosu öğrenci seviyesine uygun mu? & 4.83 & 4.66 & 4.33 & 4.66 \\
\hline $\begin{array}{l}\text { 2. Metinler iki boyutlu görsellerle (kavram haritası. zihin haritası. bilgi haritası) } \\
\text { desteklenmiş mi? }\end{array}$ & 2.56 & 2.00 & 2.33 & 2.12 \\
\hline 3. Kapak tasarımı ve boyutu öğrencinin ilgisini çekiyor mu? & 2.66 & 2.50 & 2.50 & 2.50 \\
\hline 4. Kitabın içerisindeki görseller öğrencinin anlayabileceği düzeyde mi? & 4.16 & 3.83 & 3.60 & 3.66 \\
\hline Genel Ortalama & $\begin{array}{c}3.55 \\
Y\end{array}$ & $\begin{array}{l}3.24 \\
\text { AY }\end{array}$ & $\begin{array}{l}3.19 \\
\text { AY }\end{array}$ & $\begin{array}{l}3.23 \\
\text { AY }\end{array}$ \\
\hline \multicolumn{5}{|l|}{ D. Değerlendirme } \\
\hline 1. Öğrencinin kendisini ifade etmesine yönelik sorular yeterli mi? & 3.00 & 3.16 & 3.66 & 3.33 \\
\hline 2. Ünite sonundaki testlerin kapsamı yeterli düzeyde mi? & 4.50 & 4.00 & 3.66 & 3.50 \\
\hline 3. Performans ve proje çalışmalarına yer verilmiş mi? & 3.50 & 3.00 & 3.00 & 3.00 \\
\hline 4. Öz değerlendirmeye yer verilmiş mi? & 3.33 & 2.66 & 3.00 & 3.16 \\
\hline 5. Akran değerlendirmesine yer verilmiş mi? & 2.66 & 2.33 & 2.33 & 1.83 \\
\hline 6. Etkinliklerin içinde yoruma dayalı kısımlar (Açık uçlu vb.) var mı? & 4.16 & 3.16 & 3.33 & 3.00 \\
\hline 7. Değerlendirmede bireysel farklılıklar dikkate alınıyor mu? & 2.50 & 2.33 & 2.33 & 1.83 \\
\hline $\begin{array}{l}\text { 8. İş birliğine dayalı ögrenme çalışmalarına yönelik grup değerlendirmeleri yeterli } \\
\text { mi? }\end{array}$ & 3.16 & 2.16 & 3.00 & 2.66 \\
\hline 9. Değerlendirme amaçlı kavram haritası kullanılmış mı? & 1.42 & 1.82 & 1.64 & 1.12 \\
\hline 10. Değerlendirme amaçlı tanılayıcı dallanmış ağaç tekniği kullanılmış mı? & 1.00 & 1.00 & 1.00 & 1.00 \\
\hline Genel Ortalama & $\begin{array}{l}2.25 \\
\text { ÇAY }\end{array}$ & $\begin{array}{l}2.56 \\
\text { ÇAY }\end{array}$ & $\begin{array}{l}2.68 \\
\text { AY }\end{array}$ & $\begin{array}{l}2.44 \\
\text { ÇAY }\end{array}$ \\
\hline
\end{tabular}

ÇY: Çok yeterli, Y: Yeterli, AY: Az yeterli, ÇAY: Çok az yeterli, HY: Hiç Yok 
Yapılandırmacı öğrenme yaklaşımına göre öğretim uygulamalarında öğrencilerin önceden edinmiş oldukları bilgiler ve geçmiş deneyimler öğrenmeyi kolaylaştıran ve güçlendiren zengin bir kaynak olarak görülmektedir (Deryakulu \& Şimşek, 1996: 62). Yapılandırmacı öğrenmenin uygulandığı bir öğrenci grubunda dersin giriş kısmı oldukça önemlidir. Bu bölümde öğretmen öğrencilerin ön bilgilerini açığa çıkarmaya, onlara bildiklerinin farkına vardırmaya çalışır. Bu bakımdan bir kazanıma yönelik etkinliğe başlamadan önce ön öğrenmelerin harekete geçirilmesi gerekir. Yapılandırmacı öğrenmeye uygun olarak hazırlanmış bir ders kitabının da buna uygun olması gereklidir.

Ölçeğin giriş bölümünde yer alan ölçütlerin ortalamaları incelendiğinde, ölçeğin birinci maddesinde yer alan "Ön bilgileri ortaya çıkarıcı etkinliklerin yeterlilik düzeyi nedir?” ölçütüne göre incelemeyi yapan gözlemcilerin ortalamaları 2,33 ile 3,33 arasında değişmektedir. Bu ölçüte göre en düşük ortalama $(2,33)$ ile "Öğretici Metinler" ünitesi, "çok az yeterli" aralığına denk gelmektedir. Kitabın son ünitesi olan bu bölümde ön bilgileri ortaya çıkarıcı etkinliklere çok az yer verilmiştir. Örneğin, "Metin ve Gelenek" konusundaki 1. hazırlık sorusu, "İlk özel gazete olan Tercüman-1 Ahval ile Türk Edebiyatına öğretici metinlerden makale türü girmiştir. Buna göre iletişsim araçlarıyla - dergi, gazete, televizyon, İnternet - öğretici metin türleri arasında nasıl bir ilişki kurulabilir? Tartışınız (s.191).” ile ön bilgiler harekete geçirilmeye çalışılırken diğer okuma parçalarında bu tür etkinliklere yeterince yer verilmemiştir. "Konudan önceki dikkat çekici etkinliklerin yeterlilik düzeyi” üçüncü ünitede 2,16 ortalama ile çok az yeterli bulunurken; birinci ünitede 4,16 ortalama ile yeterli bulunmuştur. Öğrenciyi derse güdüleme çalışmalarına ise ikinci ve dördüncü ünitelerde 2,33 ortalama ile çok az yer verildiği belirtilmiştir.

9. sınıf Türk Edebiyatı ders kitabı giriş etkinlikleri ve uygulamaları, belirlenen ölçütlere göre, gözlemciler tarafından birinci ünite için yeterli; ikinci ve üçüncü üniteler için az yeterli; dördüncü ünite için çok az yeterli bulunmuştur. Giriş bölümü etkinliklerinin öğrencilerin özellikle ön bilgilerini açığa çıkarması, öğrencilerin eski ve yeni bilgileri arasında ilişki kurmalarına yardımcı olması gerekir. Ancak 9. sınıf Türk Edebiyatı ders kitabında bu ölçütlerin yeterli olmadığı yapılan incelemelerde açığa çıkmıştır.

\section{Öğretim Bölümü Ölçütleri Açısından Ünite Etkinliklerinin Yapılandırmacı Öğrenme Yaklaşımına Uygunluk Düzeyi Nedir?}

Öğretim bölümünde yer alan ölçütlerin ortalamaları incelendiğinde, "Metinler orijinaline sâdık kalınarak verilmiş mi?" ölçütü en yüksek ortalama puana sahiptir. Bu ölçüte göre gözlemciler, 9. sınıf Türk Edebiyatı ders kitabının dört ünitesinde de metinlerin orijinallerine uygunluğunun yeterli olduğunu belirtmektedirler. Ancak ölçeğin öğretim alt boyutunda yer alan "Roman veya hikâyelerden alınan parçalar, yazarı hakkında öğrencide araştırma yapma isteği uyandırıyor mu?" ölçütü en düşük ortalamaya $(1,20-2,00)$ sahiptir. Buna göre gözlemciler, birinci ve ikinci ünitelerde parçaların öğrencilerde yazar hakkında çok az araştırma isteği uyandırabileceğini belirtirken, üçüncü ve dördüncü ünitelerde ise yazar hakkında hiç araştırma isteği 
uyandıramayacağını belirtmektedirler. Bu bulgular, incelenen 9. sınıf Türk Edebiyatı ders kitabının yapılandırmacı öğrenme anlayışında yer alan araştırma becerisi açısından yetersiz olduğunu göstermektedir.

Öğretim alt boyutundaki "Ders kitabı Türk dilinin etkili ve güzel kullanılmasına örnek olacak ve özendirecek şekilde düzenlenmiş mi?” ölçütü gözlemcilerce bütün ünitelerde az yeterli bulunmuştur. Ders kitaplarında imla ve noktalama yanlışlarının olması, ders kitabının öğrenciye model olmasını engelleyebilir.

Öğretim alt boyutundaki "Ünitelerdeki metinler romanın tamamını okumaya yöneltmekte yeterli mi?” ölçütü de gözlemciler tarafindan dört ünitede de çok az yeterli $(2,16-2,40)$ bulunmuştur. Bu bulguya göre yapılandırmacı ders kitabında verilen roman parçaları öğrencileri yeterince yönlendirmemektedir. Bu durum, 9. sınıf öğrencilerinin okumaya yönlendirilememesinin sebeplerinden biri olarak görülebilir.

Ölçeğin öğretim alt boyutunda yer alan "Farklı zeka türlerine yönelik etkinliklerin yeterlilik düzeyi?" ölçütü dört ünitede de gözlemciler tarafından çok az yeterli bulunmuştur. 2005 y1lından sonra kademeli olarak yenilenmeye başlanan ilköğretim ve ortaöğretim programlarının temellerinden biri de programların çoklu zekâya uygun hâle getirilerek uygulanmasıdır. Ancak 9. sınıf Türk Edebiyatı ders kitabında bu ölçütün yeterli olmadığı görülmektedir.

Öğretim alt boyutunun "Kullanılan görsel ögeler ne düzeyde model olmaktadır?” ölçütünü gözlemciler birinci ve dördüncü ünitelerde çok az yeterli, ikinci ve üçüncü ünitelerde ise az yeterli bulmuşlardır. Oysaki ders kitaplarındaki görsel ögeler, öğretim programının uygulanması açısından önemlidir.

Öğretim alt boyutunda yer alan “Öğrencileri grup çalışmasına yöneltici aktiviteler mevcut mu?” ölçütü gözlemciler tarafindan birinci ünitede yeterli; diğer ünitelerde az yeterli olarak değerlendirilmiştir. Ders kitabından elde edilen bulgularda, Harname (s. 137) okuma parçasının sonundaki 5. etkinlik (s. 140), Köy Hocası ile Sığırtmaç (s. 144) hikâyesinin sonundaki 12. etkinlik (s. 147), Dokuzuncu Hariciye Koğuşu'ndan (s. 147) sonraki 15. etkinlik (s. 154) gözlemciler tarafından öğrencileri grup çalışmasına ve işbirlikçi öğrenmeye yönlendiren etkinlikler olarak değerlendirilmiştir. Yapılandırmacı öğrenme yaklaşımında grup çalışmaları bilginin yapılandırılmasında, bireylerin iletişim becerilerinin gelişmesinde son derece önemlidir. Öğrencilerin öğretmenlerle ve birbirleriyle olan etkileşimi bilginin yapılandırılmasına katkıda bulunacaktır (Steffe \& Gale, 1995). İşbirliğine dayalı öğrenme, öğrencilerin önceki bilgilerinin değerlendirilmesinde kullanılabilen tartışma firsatları sunar (Loyens, 2007). Bu nedenle Türk Edebiyatı ders kitabında öğrencileri grup çalışmalarına yönlendirici etkinliklerin daha fazla bulunması gerekmektedir.

Gözlemciler, öğretim alt boyutundaki "Metinlerdeki imla ve noktalamaların doğru kullanılma düzeyi nedir?” ölçütünün dördüncü ünitede yeterli düzeyde, diğer ünitelerde çok yeterli düzeyde olduğunu belirtmişlerdir.

Öğretim alt boyutunda yer alan ölçütlere gözlemcilerin vermiş oldukları puanların genel ortalaması incelendiğinde gözlemciler, "Güzel Sanatlar ve Edebiyat” ünitesini 3,18 ortalama ile "Coşku ve Heyecanı Dile Getiren Metinler (Şiir)” ve "Olay 
Çevresinde Oluşan Edebi Metinler” ünitesini 3,01 ortalama ile ve "Öğretici Metinler" ünitesi 2,79 ortalama ile az yeterli bulmuşlardır.

\section{Biçim Ölçüttleri Açısından Ünite Etkinliklerinin Yapılandırmacı Öğrenme Yaklaşımına Uygunluk Düzeyi Nedir?}

YDKDÖ’nün biçim boyutunda yer alan ölçütler incelendiğinde gözlemcilerin ortalamaları, metin ve başlık puntosunun öğrenci seviyesine uygunluğunun çok yeterli olduğunu belirtmektedir. Metinlerin iki boyutlu görsellerle (kavram haritas1, zihin haritası, bilgi haritası) desteklenmesi düzeyi, bütün ünitelerde çok az yeterli bulunmuştur. Ders kitabı yapılandırmacı öğrenme yaklaşımının destek materyallerinden biri olan iki boyutlu görsel materyaller açısından yetersizdir. Sadece birinci ünitede; 2 ve 17. sayfalarda, üçüncü ünitede; 92 ve 159. sayfalarda, dördüncü ünitede 188. sayfada tam olmasa da kavram haritalarına benzer şemalar vardır. Oysa kavram haritaları, yapılandırmacı öğrenme yaklaşımında en yoğun kullanılan araçlardandır. Bu durum, Türk edebiyatı öğretim programında kazandırılmak istenen üst ve alt becerilerden iletişim becerisindeki "Düşüncelerini kavram haritalarıyla ve grafiklerle açıklar" kazanımıyla çelişmektedir.

Biçim boyutundaki "Kapak tasarımı ve boyutu öğrencinin ilgisini çekiyor mu?" ölçütünü gözlemciler birinci ünitede 2,66 ortalama ile az yeterli bulurken, diğer ünitelerde 2,50 ortalama ile çok az yeterli bulmuşlardır. Kitap kapağı öğrenme açısından yeterince merak uyandırıcı ve içerikle ilişkili olmalı, öğrenciyi kitaba yeterince yöneltebilmelidir.

Biçim boyutundaki ortalamalara göre, birinci ünitenin biçim açısından yeterli, diğer ünitelerin ise az yeterli olduğu sonucuna ulaşılmıştır.

\section{Değerlendirme Ölçütleri Açısından Ünite Etkinliklerinin Yapılandırmacı Öğrenme Yaklaşımına Uygunluk Düzeyi Nedir?}

Ölçekte yer alan değerlendirme boyutu ölçütlerine göre, "ünite sonundaki testlerin kapsamının yeterlilik düzeyi”ni genel olarak gözlemciler yeterli bulmaktadırlar. "Performans ve proje çalışmalarına yer verilme düzeyi” gözlemciler tarafindan birinci ünitede yeterli, diğer ünitelerde az yeterli bulmaktadırlar. "Öz değerlendirmeye yer verilme düzeyi” tüm ünitelerde az yeterli bulunurken “Akran değerlendirmesine yer verilme düzeyi" birinci ünitede az yeterli, diğer ünitelerde çok az yeterli bulunmaktadır. "Değerlendirmede bireysel farklılıkların dikkate alınması" gözlemciler tarafından tüm ünitelerde çok az yeterli bulunurken "Değerlendirme amaçlı kavram haritası kullanılma düzeyi”ne yönelik gözlemci ortalamaları ikinci ünitede çok az yeterli aralığına, diğer ünitelerde hiç yok aralığına denk gelmektedir. Yine "ünitelerde değerlendirme amaçlı tanılayıcı dallanmış ağaç tekniği kullanılma düzeyi”ne gözlemciler "Hiç yok" demişlerdir. Gözlemciler ölçeğin değerlendirme boyutunda yer alan ölçütlerin ders kitaplarında çok az yeterli olduğunu belirtmişlerdir. Yapılandırmacı öğrenme yaklaşımında geleneksel ölçme-değerlendirme araçları ile sürece dayalı tamamlayıcı ölçme-değerlendirme araçlarının da kullanılması gerekmektedir. Ancak Türk Edebiyatı ders kitabında daha çok geleneksel ölçme-değerlendirme araçlarının kullanıldığı, 
tamamlayıcı ölçme araçlarının ya çok yetersiz olduğu ya da hiç olmadığı gözlemciler tarafından belirtilmiştir. Ders kitabında her konunun sonunda yer alan öz eleştiri tabloları öz değerlendirme amacıyla kullanılabilir. Ancak gözlemciler tarafından yeterli bulunmamıştır. Akran değerlendirmesine “Tiyatro” konusundaki Hamlet parçasının 3. etkinliğinde yer verilmiş. Ancak ünite genelinde çok az yeterli olduğu tespit edilmiştir. Ünite sonralarında verilen boşluk doldurma, çoktan seçmeli, doğru-yanlış tipi testlere tamamlayıcı ölçme araçlarından daha fazla yer verilmesi, 9. sınıf Türk Edebiyatı ders kitabının geleneksellikten tam olarak kurtulamadığının bir göstergesi olarak alg1lanabilir.

Giriş, Öğretim, Biçim ve Değerlendirme Ölçütlerine Göre Gözlemci Ortalamaları Arasında Üniteler Açısından Anlamlı Bir Farklılık Var Mıdır?

Gözlemci ortalamalarının ünitelere göre anlamlı bir farklılık gösterip göstermediğini belirlemek için tek yönlü varyans analizi yapılmıştır.

Tablo 3

Gözlemci Ortalamalarına Uygulanan Tek Yönlü Varyans Analizi Sonuçları

\begin{tabular}{|c|c|c|c|c|c|c|c|}
\hline Alt Boyut & Ünite & $\begin{array}{c}N \\
\text { (ölçüt } \\
\text { sayısı) }\end{array}$ & $X$ & SS & $F$ & $p$ & $\begin{array}{c}\text { Tukey } \\
\text { HSD (Anlamlı fark) }\end{array}$ \\
\hline \multirow{4}{*}{ 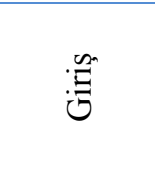 } & I & 5 & 3.49 & .43 & \multirow{4}{*}{9.36} & \multirow{4}{*}{$\begin{array}{c}.001 \\
p<.05\end{array}$} & \multirow{4}{*}{$\begin{array}{l}1-2(p=.013) p<.05 \\
1-3(p=.005) p<.05 \\
1-4(p=.001) p<.05\end{array}$} \\
\hline & II & 5 & 2.73 & .383 & & & \\
\hline & III & 5 & 2.63 & .322 & & & \\
\hline & IV & 5 & 2.43 & .148 & & & \\
\hline \multirow{4}{*}{ 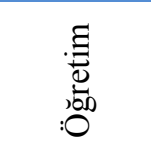 } & I & 19 & 3.18 & .726 & \multirow{4}{*}{1.16} & \multirow{4}{*}{$\begin{array}{c}.331 \\
p>.05\end{array}$} & \multirow{4}{*}{$p>.05$} \\
\hline & II & 19 & 3.01 & .632 & & & \\
\hline & III & 19 & 3.08 & .632 & & & \\
\hline & IV & 19 & 2.79 & .698 & & & \\
\hline \multirow{4}{*}{.: } & I & 4 & 3.55 & 1.122 & \multirow{4}{*}{.089} & \multirow{4}{*}{$\begin{array}{c}.96 \\
p>.05\end{array}$} & \multirow{4}{*}{$p>.05$} \\
\hline & II & 4 & 3.24 & 1.217 & & & \\
\hline & III & 4 & 3.19 & .945 & & & \\
\hline & IV & 4 & 3.23 & 1.153 & & & \\
\hline \multirow{4}{*}{ 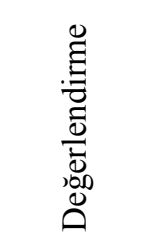 } & I & 10 & 2.92 & 1.094 & \multirow{4}{*}{.484} & \multirow{4}{*}{$\begin{array}{c}.696 \\
p>.05\end{array}$} & \multirow{4}{*}{$p>.05$} \\
\hline & II & 10 & 2.56 & .832 & & & \\
\hline & III & 10 & 2.69 & .869 & & & \\
\hline & IV & 10 & 2.44 & .923 & & & \\
\hline \multirow{4}{*}{ 巳্ঠ } & I & 38 & 3.19 & .846 & \multirow{4}{*}{2.661} & \multirow{4}{*}{.050} & \multirow{4}{*}{$1-4(p=.030) p<.05$} \\
\hline & II & 38 & 2.88 & .743 & & & \\
\hline & III & 38 & 2.93 & .713 & & & \\
\hline & IV & 38 & 2.69 & .785 & & & \\
\hline
\end{tabular}

Belirlenen ölçütlere göre, gözlemci ortalamaları arasındaki farkın anlamlı olup olmadığına yönelik yapılan tek yönlü varyans analizi sonuçlarına bakıldığında giriş alt boyutuna yönelik ölçütlerin ortalamasına göre I. ünite 3,49 ortalama ile en yüksek; IV. ünite 2,43 ortalama ile en düşük değere sahiptir. Ders kitabında yer alan giriş 
etkinlikleri açısından üniteler arasındaki fark anlamlıdır $(p<.05)$. Anlamlı farkın kaynağını tespit etmek için yapılan Tukey HSD testi sonuçlarına göre birinci ünite, diğer ünitelerden anlamlı düzeyde farklıdır $(p<.05)$. Ancak, öğretim, biçim ve değerlendirme alt boyutlarında yer alan ölçütlerin ortalamaları arasında üniteler düzeyinde anlamlı farklılık yoktur ( $p>.05)$. Tüm ölçütlerin ortalamaları dikkate alınarak hesaplanan tek yönlü varyans analizi sonucuna göre, üniteler arasında anlamlı bir farklılık vardır $(p<.05)$. Farkın kaynağını tespit etmek için yapılan Tukey HSD testi sonuçlarına göre fark, birinci ve dördüncü ünitelerin ortalamalarından kaynaklanmaktadır. Bu üniteler arasındaki fark anlamlıdır $(p<.05)$.

\section{Sonuç ve Tartışma}

Günümüzde bireylerden bilgi tüketmekten çok bilgi üretmeleri beklenmektedir. Çağdaş dünyanın kabul ettiği birey, kendisine aktarılan bilgileri aynen kabul eden, yönlendirilmeyi ve biçimlendirilmeyi bekleyen değil, bilgiyi yorumlayarak anlamın oluşturulması sürecine etkin olarak katılanlardır (Yıldırım \& Şimşek, 2000: 9). Yapılandırmacı öğrenme yaklaşımının temelinde de bu anlayış yatmaktadır. Son yıllara kadar ders kitabı öğrencinin bilgiye ulaşabileceği tek kaynak olarak düşünülmekte ve buna göre biçimlendirilmektedir. Oysaki yapılandırmacı öğrenme yaklaşımıyla öğretmen ve öğrenci rollerinde olduğu gibi ders kitaplarının rolü de değişmiştir. Ders kitapları artık bilgiye ulaşmanın tek kaynağı değildir. Aksine öğrencinin bilgiyi oluşturmasında, diğer bilgi kaynaklarına yönlendirilmesinde daha etkili olmalıdır. Bilgi ve öğrenen arasında doğrudan iletişim sağlayan ders kitapları, bireyin yaşadığı dünyayı anlaması için açılım yapan bir materyal hâline gelmiştir.

Ülkemizde 2005 ilköğretim programlarıyla başlayan yapılandırmacı süreç, ortaöğretim programlarıyla devam etmektedir. $\mathrm{Bu}$ süreçte ders kitapları da yapılandırmacı öğrenme yaklaşımına uygun olarak hazırlanmaya başlanmıştır. Ancak ilköğretimden ortaöğretime hazırlanan ders kitaplarının ne düzeyde yapılandırmacı olduğu yapılan araştırmalarla değerlendirilmektedir. Bu araştırmada da 9. sınıf Türk Edebiyatı ders kitabının yapılandırmacı öğrenme yaklaşımına uygunluğu açısından değerlendirilmesiyle eksikliklerin giderilmesine yardımcı olmak amaçlanmıştır.

Araştırmanın bulgularından çıkartılan sonuçlara göre; giriş bölümü etkinliklerinin birinci ünitede yeterli, ikinci ve üçüncü ünitelerde az yeterli, dördüncü ünitede çok az yeterli olduğu sonucuna ulaşılmıştır. Bu bölümde yer alan ölçütlerden “Ön bilgileri ortaya çıkarıcı etkinliklerin yeterlilik düzeyi nedir?” ölçütünün ortalamasının özellikle üçüncü ve dördüncü ünitelerde yeterli olduğu söylenemez. Oysaki yapılandırmacı öğrenme yaklaşımında ön bilgilerin açığa çıkarılması son derece önemlidir. Yapılandırmacı öğrenme kuramını benimsemiş araştırmacılara göre öğrencilerin konu ile ilgili ön bilgileri, yeni öğrenilecek bilgiyi büyük ölçüde etkilediğinden çok büyük bir öneme sahiptir (Duit \& Treagust 1998, aktaran Küçüközer ve diğerleri, 2008). Oysa ortaöğretim 9. sınıf Türk Edebiyatı ders kitabının ön bilgileri yeterince harekete geçirdiği söylenemez. 
Araştırmada kullanılan ölçeğin öğretim bölümünde yer alan ölçütlere dayalı sonuçlar incelendiğinde ölçeğin "Ünitelerdeki metinler romanın tamamını okumaya yöneltmekte yeterli mi?” ölçütünün ortalaması 2,16 ile 2,40 arasında değişmektedir. Bu ortalamalara göre metinlerin romanın tamamını okumaya yöneltme düzeyi çok az yeterli bulunmuştur. Yine aynı şekilde ölçeğin roman veya hikâyelerden alınan parçaların yazar hakkında öğrencide araştırma isteği uyandırma düzeyi, birinci ve ikinci ünitelerde 2,00 ortalama ile çok az yeterliyken, üçüncü ünitede 1,66 ortalama ile, dördüncü ünitede 1,20 ortalama ile yetersiz olarak görülmektedir. Ölçeğin görsel ögelerin model olmasıyla ilgili ölçütünün ortalamasına göre birinci ve dördüncü üniteler, 2,00 ortalama ile çok az yeterli iken üçüncü ve dördüncü üniteler 2,83 ortalama ile az yeterlidir. Oysa ders kitaplarında görsel ögelerin önemi kaçınılmazdır. Eşgi (2005), "İlköğretim 5. sınıf Bilgisayar Ders Kitaplarının Görsel Tasarım İlkelerine Göre Değerlendirilmesi” isimli çalışmasında, görsel tasarım ilkelerini bütünüyle dikkate alan bir ders kitabının hazırlanmadığı sonucuna varmıştır. Alpan (2004), ders kitaplarında yer alan görsel ögelerin, "Görsellere yer verdim” kaygısıyla gerçekleştirilmekte olduğunu, bu kaygıyla gerçekleştirilen görsel ögelerin nitelik ve nicelik açısından yeterli olmadığını savunmaktadır. Ölçeğin öğretim bölümünde yer alan on dördüncü ölçütü (Problemler, olaylar üzerinde yeni fikir ve çözümler buldurucu etkinlikler yeterli mi?), özellikle ikinci ünitede az yeterli bulunmuştur. Oysa yapılandırmacı öğrenme yaklaşımının temellerinden biri, öğrenciyi problem çözmeye düşünmeye yönlendirmektir. Öğrencilerin kavramları doğru yapılandırabilmesi için öğrencilere keyif verecek, dikkatlerini ve meraklarını uyandıracak, sürpriz öğrenme ortamlarının düzenlenmesi gerekir (Senemoğlu, 2009). Ders kitaplarının da bu ortamların düzenlenmesine katkı sağlaması, 9. sınıf Türk Edebiyatı öğretim programının başarıya ulaşması açısından önemlidir. Ölçeğin öğretim bölümünün ölçütlerinin genel ortalaması sonuçlarına göre bu bölümde yer alan ölçütler açısından ders kitapları az yeterli görülmektedir.

Araştırmada kullanılan ölçeğin biçim alt boyutunda yer alan ölçütlere yönelik sonuçlar incelendiğinde ölçeğin ikinci ölçütünün (Metinler iki boyutlu görsellerle ((kavram haritası, zihin haritası, bilgi haritası)) desteklenmiş mi?) ortalaması bütün ünitelerde "Çok az yeterli" aralığına denk gelmektedir. 9. sınıf Türk Edebiyatı ders kitabında görülen bu iki boyutlu görsellerin eksikliği, öğretim programının başarısını düşürebilir. İki boyutlu görsel öğrenme araçları, öğrenme stratejilerinin anlamlandırma ve örgütleme aşamaları ile ilişkili olduğundan öğrencilere bu araçları kullanmaları öğretilmelidir (Yalın, 2007). Öğrenme stratejilerini kullanan öğrenci, bilgiyi kendi anlayabileceği biçimde yeniden yapılandırır. Bu yapılandırma sürecinde öğrenci içsel ve dışsal olmak üzere birtakım güçlüklerle karşılaşır. Bilgiyi yapılandırmayı engelleyen güçlüklerin temelinde öğrencinin kişilik özelliğinden kaynaklanan içsel faktörler olabileceği gibi iyi tasarlanmamış ders kitapları gibi dışsal faktörler de olabilir. Bu bağlamda ders kitaplarının gerek içeriğinin gerekse biçimsel özelliklerinin öğrenciyi bilgiyi yapılandırmaya yöneltecek biçimde tasarlanmış olması gerekir. Ders kitabı tasarlamaya başlamadan önce yapılandırmacı öğrenme yaklaşımının özelliklerinin çok iyi araştırılması gerekir. Ancak yapılan araştırmalarda durum pek de böyle değildir. Milne (2008), “Queensland Okullarında Yapılandırmacı Öğretim Programı İle 
Kullanımı İçin Tavsiye Edilen Ortaokul Bilim Ders Kitapları Çalışması" adlı çalışmasında incelediği ders kitaplarının hepsinde yapılandırmacı öğrenme yaklaşımının en az bir boyutunun eksik olduğu, araştırmaya yönlendirmediği, gerçek yaşam problemleriyle öğrencilerin karşılaştırılmadığı vb. sonuçlara ulaşmıştır. Ölçeğin biçim boyutundaki ölçütlerin genel ortalamalarına göre birinci ünite biçim açısından yeterli bulunurken diğer üç ünite az yeterli bulunmuştur. $\mathrm{Bu}$ anlamda 9. sinıf Türk edebiyatı ders kitaplarının biçim açısından da gözden geçirilmesi gerekir.

Araştırmada kullanılan ölçeğin değerlendirme alt boyutunda yer alan ölçütlere yönelik sonuçlar incelendiğinde 9. sınıf Türk Edebiyatı ders kitabında daha çok yapılandırmacı öğrenme yaklaşımı içerisinde yer alan otantik değerlendirmeye yönelik kullanılan tamamlayıcı ölçme araçlarında (öz değerlendirme, akran değerlendirmesi, kavram haritaları, tanılayıcı dallanmış ağaç) sorunlar olduğu sonucuna ulaşılmıştır. Değerlendirme ile ilgili genel ortalamalar da bu sonuçları destekler niteliktedir. Nitekim, değerlendirme boyutunda yer alan ölçütler açısından üçüncü ünite ortalamaları az yeterli bulunurken, diğer ünite ortalamaları bu anlamda çok az yeterli bulunmuştur. $\mathrm{Bu}$ sonuçlara göre, yapılandırmacı öğrenme yaklaşımının doğasında var olan gerçek durumlara dayalı değerlendirme, 9. sınıf Türk Edebiyatı ders kitabında yer almamaktadır. Oysa otantik değerlendirme araçlarından akran değerlendirmesi ve öz değerlendirmenin öğrenme ortamında kullanılması, öğretmen geri bildirimi ile öğrenci öğrenmesi arasında güçlü bir bağ oluşturmaktadır (Fer \& Cırık, 2007).

Ülkemizde 2005 yılıyla birlikte ilköğretim programlarından başlayan değişim süreci, öğretim programının diğer boyutlarını etkilediği gibi ölçme-değerlendirme boyutunu da etkilemiştir. Sürece dayalı ölçme-değerlendirmede öğrencileri öğrenme ortamında desteklemek ve sahip oldukları yetenekleri yazılı, sözlü ve eylemsel olarak ortaya çıkarmak amaçlanmaktadır (Çepni, 2007). Bu amaca uygun olarak tasarlanmış olan tamamlayıcı ya da alternatif ölçme araçları olarak bilinen portfolyo, tanılayıcı dallanmış ağaç, öz değerlendirme, akran değerlendirmesi, kavram haritaları vb. ölçme araçlarının süreçte kullanılması gerekmektedir çünkü bu araçlar, bir taraftan öğrencilerin öğrenme güçlüklerini çoklu verilere dayalı olarak açığa çıkartırken, diğer taraftan öğretim sürecinde sürekli iyileştirmeler yapılmasına rehberlik eder. Ayrıca, bu araçlar bireyin yeteneğini sergilerken kullandığı bilişsel, duyuşsal ve devimsel özelliklerin bütünü olarak tanımlanan üst düzey zihinsel becerileri (Kutlu, Doğan, \& Karakaya, 2008) açığa çıkarmada da etkilidir. Şüphesiz, yapılandırmacı öğrenme yaklaşımında azımsanamayacak düzeyde yararları bulunan tamamlayıcı ölçme araçlarının da ders kitaplarında bulunması gereklidir. Bu araçların 9. sınıf Türk Edebiyatı ders kitabında bulunmaması önemli bir eksiklik olarak vurgulanabilir.

Gözlemci ortalamalarının ünitelere göre anlamlı bir farklılık gösterip göstermediğini belirlemek için yapılan analiz sonuçlarına göre ölçeğin alt boyutlarından giriş etkinliklerindeki ve ölçeğin üniteler düzeyinde genel ortalamaları arasındaki fark anlamlıdır.

Yapılan araştırmada kullanılan ölçeğin ünitelere göre genel ortalaması incelendiğinde, ders kitabında üçüncü ünitenin yapılandırmacı öğrenme anlayışı 
açısından az yeterli olduğu, diğer üç ünitenin ise çok az yeterli olduğu sonucuna ulaşılmıştır. Bu anlamda 9. sınıf Türk edebiyatı ders kitabının yapılandırmacı öğrenme anlayışına uygun olarak yeniden düzenlenmesi öğretim programı açısından önemlidir. Yapılandırmacı öğrenme yaklaşımında her ne kadar belirgin bir ders kitabına bağlılık söz konusu olmasa da, henüz ülkemizde öğretmenlerin ders kitabından kopamadığ düşünüldüğünde ders kitaplarının yapılandırmacı öğrenme yaklaşımının özelliklerine uygun hâle getirilmesi faydalı olacaktır.

\section{Kaynakça}

Alkan, C., Deryakulu, D., \& Şimşek, N. (1995). Eğitim teknolojisine giriş. Ankara: Önder Matbaacilık

Alpan, G. (2004). Ders kitaplarındaki grafik tasarımının öğrenci başarısına ve derse ilişkin tutumlarına etkisi (Yayımlanmamış doktora tezi). Ankara Üniversitesi, Ankara.

Arı, E., \& Bayram, H. (2012). Yapılandırmacı yaklaşıma dayalı kimya laboratuar uygulamalarının öğrencilerin başarısına, bilimsel süreç becerilerine ve laboratuar performanslarına etkisi. Western Anatolia Journal of Educational Science, 3(6), 118. http://web.deu.edu.tr/baed adresinden indirilmiştir. [Erişim tarihi: 10.4.2012]

Blumenfeld, P. C. (1992). Classroom learning and motivation: Clarifying and expanding goal theory. Journal of Educational Phychology, 84(3), 272-281.

Büyükkaragöz, S., \& Sarı, H. (1997). İlkokullarda başarılı bir öğrenme nasıl gerçekleştirilir? Ĕgitim ve Bilim, 21(105)

Büyüköztürk, S. (2007). Veri analizi el kitabı. Ankara: Pegem Akademi Yayıncılık.

Çepni, S. (2007). Performans değerlendirme. E. Karip (Ed.) içinde, Ölçme ve değerlendirme (ss. 193-239). Ankara: Pegem Akademi Yayıncılık.

Demirci, C. (2008) Fen bilgisi 6, 7, ve 8. sınıf ders kitaplarının değerlendirilmesi. Hacettepe Üniversitesi Eğitim Fakültesi Dergisi, 33, 108-119. http://193.140.216.63/200733CAVİDE\%20DEMİRCİ.pdf adresinden indirilmiştir. [Erişim tarihi: 10.4.2012]

Deryakulu, D. (2000). Yapıcı öğrenme. A. Şimşek (Ed.) içinde, Sınıfta demokrasi (ss. 53-77). Ankara: Eğitim Sen Yayınları.

Deryakulu, D., \& Şimşek, A. (1996). Türetimci öğrenme stratejileri ve dikkat odaklama araçlarının metinden öğrenmeye etkisi. 3. Ulusal Eğitim Bilimleri Kongresinde sunulmuş sözlü bildiri, Uludağ Üniversitesi, Bursa.

Duman, B. (2004). Öğrenme-öğretme kuramları ve süreç temelli ögrretim. Ankara: Anı Yayınc1lik.

Duman, B. (2008). Eğitimde çağdaş yaklaşımlar. Gürbüz Ocak (Ed.) içinde Öğretim ilke ve yöntemleri(2. Bask1, 277-352). Ankara: Pegem Akademi Yayıncılık.

Eşgi, N. (2005). İlköğretim 5. sınıf bilgisayar ders kitaplarının görsel tasarım ilkelerine göre değerlendirilmesi. MEB Ĕgitim ve Sosyal Bilimler Dergisi, 165, 
http://yayim.meb.gov.tr/dergiler/165/esgi.htm adresinden indirilmiştir. [Erişim tarihi: 10.4.2012]

Fer, S., \& Cırık, İ. (2007). Yapılandırmacı öğrenme kuramdan uygulamaya. İstanbul: Morpa Yayınları.

Kılıç, Z., Atasoy, B., Tertemiz, N., Şeren, M., \& Ercan, L. (2001). Fen bilgisi 4-8 konu alanı ders kitabı inceleme kılavuzu. Ankara: Nobel Yayın Dağıtım.

Köseoğlu, F., Atasoy, B., Kavak, N., Akkuş, H., Budak, E., Tümay, H., ... Tasdelen, U. (2003). Yapılandırmacı ögrenme ortamı için bir fen ders kitabı nasıl olmalı? (1. bask1). Ankara: Asil Yayın Dagıtım.

Kurt, A., Demir, E., Berber, T.B., Çiftçi, G., Özlük, N. vd. (2009). Türk Edebiyatı 9. sinıf (3. bask1). Ankara: Devlet Kitapları.

Kutlu, Ö., Doğan, C. D., \& Karakaya, İ. (2008). Öğrenci başarısının belirlenmesi. Ankara: Pegem Akademi Yayıncılık

Küçüközer, H., Bostan, A., Kenar, Z., Seçer, S., \& Yavuz, S. (2008). Altıncı sınıf fen ve teknoloji ders kitaplarının yapılandırmacı öğrenme kuramına göre değerlendirilmesi. İlköğretim Online, 7(1), 111-126. http://ilkogretim-online.org.tr adresinden indirilmiştir. [Erişim tarihi: 10.4.2012]

Loyens, S. M. M., Rikers, R. M. J. P., \& Schmidt, H. G. (2007). The impact of students' conceptions of constructivist assumptions on academic achievement and drop-out. Studies in Higher Education, 32(5), 581-602. doi: 10.1080/03075070701573765

Loyens, S. (2007). Students' conceptions of constructivist learning (Unpublished doctoral dissertation). Erasmus Universiteit, Rotterdam, Netherlands. Retrieved from http://hdl.handle.net/1765/9264. [retrieved April, 15, 2012]

Milli Eğitim Bakanlı̆̆ı Ders Kitapları ve Eğitim Araçları Yönetmeliği. (1995). http://mevzuat.meb.gov.tr/html/22297_0.html adresinden indirilmiştir. [Erişim tarihi: 10.3.2012]

Milne, C. (2008). Study of middle school science textbooks recommended for use with a constructivist syllabus in Queensland schools (Unpublished master's of philosophy thesis). The University of Queensland, Brisbane, Avustralya http://espace.library.uq.edu.au/view/UQ:185237 adresinden indirilmiştir.[retrieved April, 15, 2012]

Ocak, G., \& Yurtseven, R. (2009). Beşinci sınıf sosyal bilgiler ders kitaplarının yapılandırmacı öğrenme yaklaşımına göre değerlendirilmesi. Balıkesir Üniversitesi Sosyal Bilimler Enstitüsü Dergisi, 12(22), 94-109.

Özden, Y. (2003). Sınıf içinde öğrenme öğretme ortamının düzenlenmesi. E. Karip (Ed.) içinde, Sınıf yönetimi (3. baskı, 36-69) ). Ankara: Pegem Akademi Yayıncılık.

Senemoğlu, N. (2009). Gelişim öğrenme ve öğretim (14. baskı). Ankara: Pegem Akademi.

Steffe, L. P., \& Gale, J. (1995). Constructivism in education. Hillsdale, NJ: Lawrence Erlbaum Associates. 
Şaşan, H. H. (2002). Yapılandırmacı öğrenme. Yaşadıkça Ĕ̆itim, 74-75, 49-52. http://talimterbiye.mebnet.net adresinden indirilmiştir. [Erişim tarihi: 9.4.2012]

Şimşek, N. (2004). Yapılandırmacı öğrenme ve öğretime eleştirel bir yaklaşım. Eğitim Bilimleri ve Uygulama Dergisi, 3(5), 115-139. Ankara: PegemA Yayınevi.

Şimşek, H. (t. y.). Pozitivism ötesi paradigmatik dönüşüm ve eğitim yönetiminde kuram ve uygulamada yeni yaklaşimlar http:/www.byclb.com/kobi/ egitim_kurumlari/ Default.aspx?KonuID=135 adresinden indirilmiştir. [Erişim tarihi: 12.4.2012]

Tekin, H. (1996). Eğitimde ölçme ve degerlendirme. Ankara: Yargı Yayınları.

Ülgen, G, (1994). Eğitim psikolojisi: Kavramlar, ilkeler, yöntemler, kuramlar ve uygulamalar. Ankara: Lazer Ofset.

Yalın, H. İ. (2007). Öğretim teknolojileri ve materyal geliştirme (19. baskı). Ankara: Nobel Yayın Dağıtım.

Yaşar, Ş. (1998). Yapısalcı kuram ve öğrenme-öğretme süreci. Anadolu Üniversitesi Eğitim Fakültesi Dergisi, 8(1-2), 68-75.

Yıldırım, A., \& Şimşek, H. (2000). Sosyal bilimlerde nitel araştırma yöntemleri. Ankara: Seçkin Yayıncılık. 